Article

\title{
Oligonucleotide Tagging for Copper-Free Click Conjugation
}

\author{
Anup M. Jawalekar ${ }^{1}$, Sudip Malik ${ }^{1}$, Jorge M. M. Verkade ${ }^{2}$, Brian Gibson ${ }^{3}$, Nancy S. Barta ${ }^{3}$, \\ John C. Hodges ${ }^{3}$, Alan Rowan ${ }^{1}$ and Floris L. van Delft ${ }^{1,2, *}$
}

1 Radboud University Nijmegen, Institute for Molecules and Materials, Heyendaalseweg 135, 6525 AJ Nijmegen, The Netherlands; E-Mails: jawanup@yahoo.com (A.M.J.); psusm2@iacs.res.in (S.M.); a.rowan@science.ru.nl (A.R.)

2 SynAffix BV, Heyendaalseweg 135, 6525 AJ Nijmegen, The Netherlands;

E-Mail: j.verkade@synaffix.com

3 Berry and Associates, Inc., 2434 Bishop Circle East, Dexter, MI 48130, USA;

E-Mails: bgibson@berryassoc.com (B.G.); nbarta@berryassoc.com (N.S.B.);

jhodges@berryassoc.com (J.C.H.)

* Author to whom correspondence should be addressed; E-Mail: f.vandelft@science.ru.nl;

Tel.: +31-24-365-2373; Fax: +31-24-365-3393.

Received: 19 April 2013; in revised form: 24 May 2013 / Accepted: 5 June 2013 /

Published: 24 June 2013

\begin{abstract}
Copper-free click chemistry between cyclooctynes and azide is a mild, fast and selective technology for conjugation of oligonucleotides. However, technology for site-specific introduction of the requisite probes by automated protocols is scarce, while the reported cyclooctynes are large and hydrophobic. In this work, it is demonstrated that the introduction of bicyclo[6.1.0]nonyne $(\mathrm{BCN})$ into synthetic oligonucleotides is feasible by standard solid-phase phosphoramidite chemistry. A range of phosphoramidite building blocks is presented for incoporation of $\mathrm{BCN}$ or azide, either on-support or in solution. The usefulness of the approach is demonstrated by the straightforward and high-yielding conjugation of the resulting oligonucleotides, including biotinylation, fluorescent labeling, dimerization and attachment to polymer.
\end{abstract}

Keywords: copper-free click; oligonucleotide conjugation; bicyclononyne; azide; strain-promoted cycloaddition 


\section{Introduction}

Synthetic DNA and RNA oligonucleotides (ONs) are key tools in a broad variety of diagnostic and therapeutic applications, including microarray technology [1], antisense and gene-silencing therapies [2], nanotechnology [3] and materials sciences [4,5]. Generally, such applications require the introduction of a suitable handle in an oligonucleotide to enable selective conjugation to a functionality of interest [6-8]. For example, attachment of a cell-penetrating ligand is the most commonly applied strategy to tackle the low internalization rate of ONs into target cells [2], currently the main bottleneck in oligonucleotide-based therapeutics (antisense, siRNA). Similarly, the preparation of oligonucleotide-based microarrays requires the selective immobilization of ONs on a suitable solid surface, e.g., glass [1]. Conventional post-synthetic labeling protocols, based on amide bond formation or sulfide-based chemistry [8-10] typically suffer from low yield and long reaction times and often require a high concentration of the biomolecule in combination with a large excess of coupling partner. One promising alternative to the traditional conjugation technologies involves the copper-catalyzed cycloaddition of alkynes and azides, a procedure commonly referred to as "click reaction" $[11,12]$. However, the use of copper for oligonucleotide conjugation may be compromised due to potential metal-catalyzed strand degradation and/or difficulties in final purification [13-15]. Although new ligands reduce the chance of undesired chain cleavage during copper-catalyzed click reaction [16-18], strain-promoted azide-alkyne cycloaddition (SPAAC) offers the possibility of oligonucleotide conjugation in the absence of copper [19-23] as demonstrated for oligonucleotides labeled with plain cyclooctyne (OCT) [15] or the more reactive dibenzofused cyclooctyne DIBO [24]. Most recently, Brown et al. [25,26] further extended the latter approach by $\mathrm{ON}$ incorporation of aminoalkyl thymidine derivatives, followed by selective $N$-acylation with azide or cyclooctyne after cleavage from support. Alternative approaches for the preparation of azide-containing nucleotides-compromised by the incompatibility of azide with phosphoramidite chemistry-involve post-synthetic nucleophilic substitution [27-29] or selective diazotransfer reaction [30] or phosphonate-based coupling chemistry [31-34] However, a simple and general strategy for the on-support, automated synthesis of oligonucleotides with readily accessible building blocks, and suitable for introduction of any functional group (including cyclooctyne and azide), is still desirable.

We here report two versatile approaches for conjugation of oligonucleotides by strain-promoted azide-alkyne cycloaddition. First, a range of novel phosphoramidite building blocks was developed for incorporation of bicyclo[6.1.0]nonyne (BCN) [35] and an adenosine-based building block is presented suitable for $\mathrm{BCN}$ or azide introduction following standard oligonucleotide synthesis protocols, and allowing multiple nucleotide 2'-functionalization (Figure 1). The ease of operation of copper-free click conjugation is demonstrated for a range of functional groups, by oligonucleotide dimerization, and by the preparation and characterization of an amphiphilic polythiophene-oligonucleotide hybrid polymer. 
Figure 1. Structures of $\mathrm{BCN}$ - and adenosine-based phosphoramidites for incorporation into and copper-free conjugation of oligonucleotides.

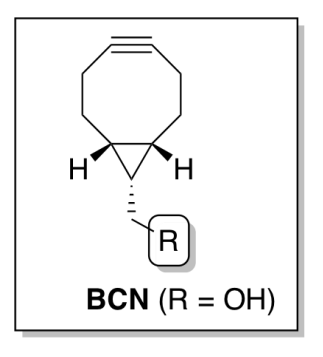

$$
\begin{aligned}
& \mathrm{R}=\sin _{s_{2}} \stackrel{\mathrm{O}^{-} \mathrm{P}^{-} \mathrm{N}(i-\mathrm{Pr})^{2}}{\mathrm{CN}}
\end{aligned}
$$

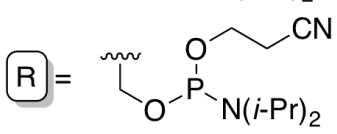

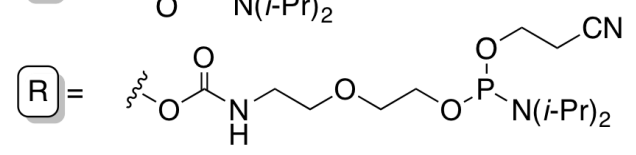

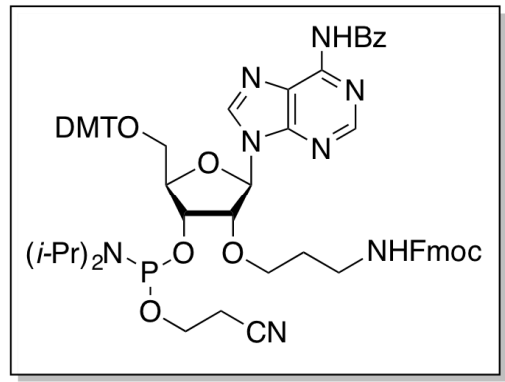

\section{Results and Discussion}

\subsection{5'-Labeling and Conjugation of Oligonucleotides}

\subsubsection{Preparation of BCN-Phosphoramidites}

Earlier reported approaches for copper-free conjugation of oligonucleotides were based solely on DIBO, a dibenzofused cyclooctyne that inevitably leads to a mixture of regioisomeric and diastereomeric adducts upon reaction with azide. We reasoned that bicyclo[6.1.0]nonyne (BCN) has particular potential for oligonucleotide conjugation, due to its higher reactivity in comparison to DIBO, its relatively low lipophilicity in comparison all dibenzofused cyclooctynes [36], and its plane-symmetry, which precludes the formation of regioisomers upon cycloaddition. Thus, phosphoramidite derivative 1 was, prepared in a single step from commercially available $\mathrm{BCN}$ alcohol $(\mathrm{R}=\mathrm{OH})$ with $81 \%$ yield (Scheme 1), as well as a diethyleneglycol chain-extended phosphoramidite 2.

Scheme 1. Synthesis of BCN-phosphoramidites 1 and 2.

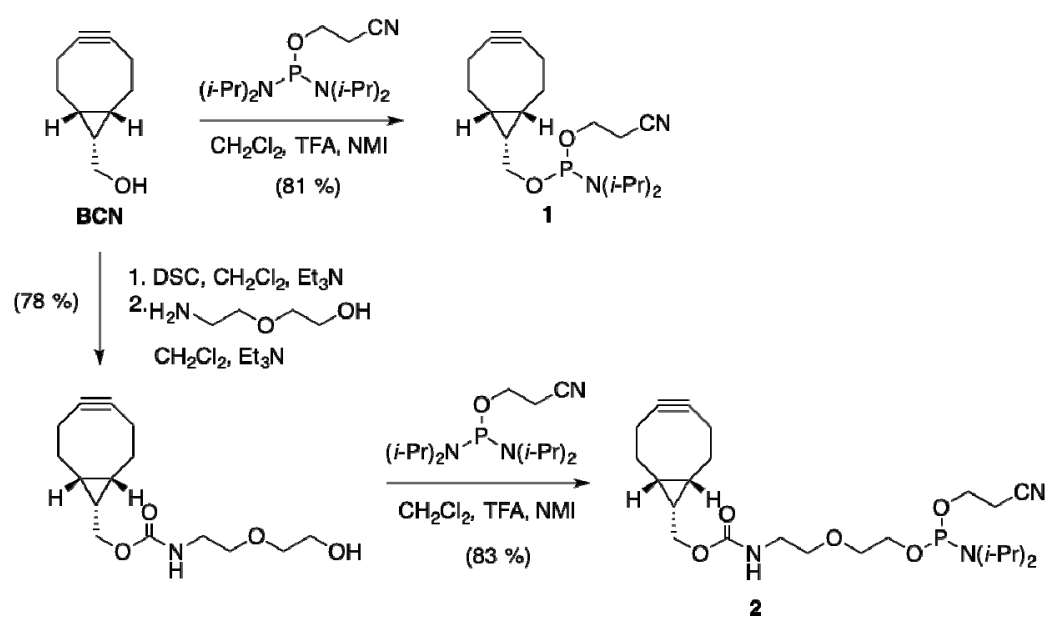

\subsubsection{Activation and Incorporation of BCN-Phosphoramidites}

Next, compound 1 was activated with 5-ethylthiotetrazole (ETT) and attached to hexathymidine nucleotide $(3, \mathrm{n}=6)$, supported on controlled pore glass (Scheme 2), leading to a single ON after oxidation and cleavage from support, as indicated by HPLC. However, mass spectrometry indicated 
that not the expected $\mathrm{BCN}$-containing diester 5, but 5'-monophosphate 4 had been isolated instead. We attribute the formation of $\mathbf{4}$ to rapid hydrolysis of the transiently formed diester phosphate $\mathbf{5}$, presumably involving a heterolytic cleavage mechanism with formation of a surprisingly stable BCN-derived cyclopropylmethyl cation [37]. Based on the latter assumption, phosphoramidite 2 was next subjected to the same oligonucleotide synthesis protocol, now leading to the isolation of the desired 5'-BCN-containing hexanucleotide 6 in high yield. Another successful strategy to avoid the formation of a cyclopropylmethyl cation involved the preparation of hexathymidine conjugate ON 7 , containing a homologated BCN ethyl derivative (Scheme 3).

Scheme 2. Solid-phase synthesis of BCN-charged oligonucleotides 5-8.
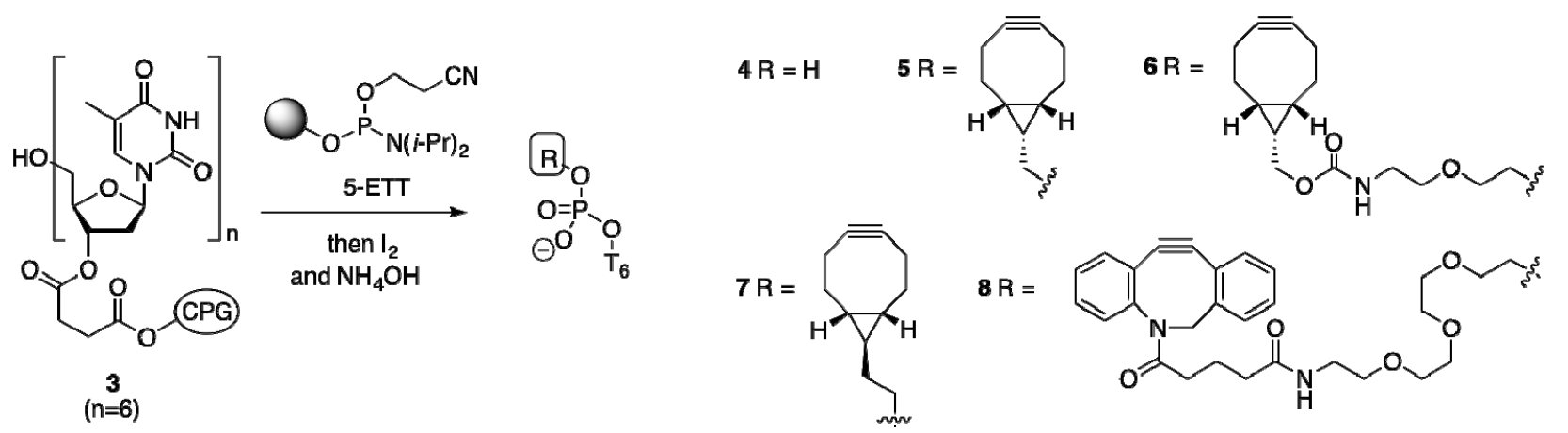

Scheme 3. Synthesis of exo-BCN-ethanol phosphoramidite for the preparation of 7.<smiles>OCC1CCCC=CCCC1</smiles>

30

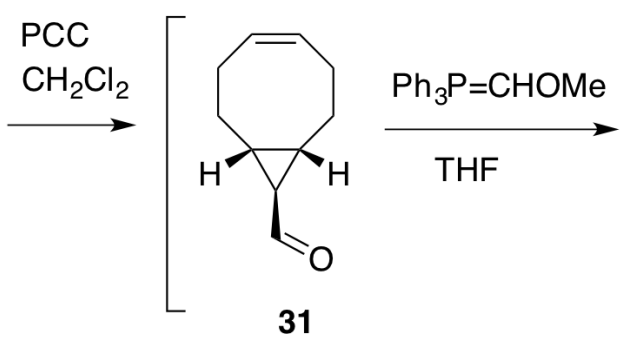

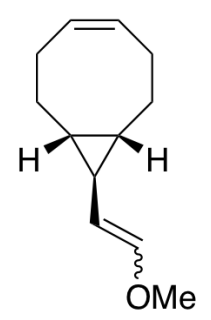
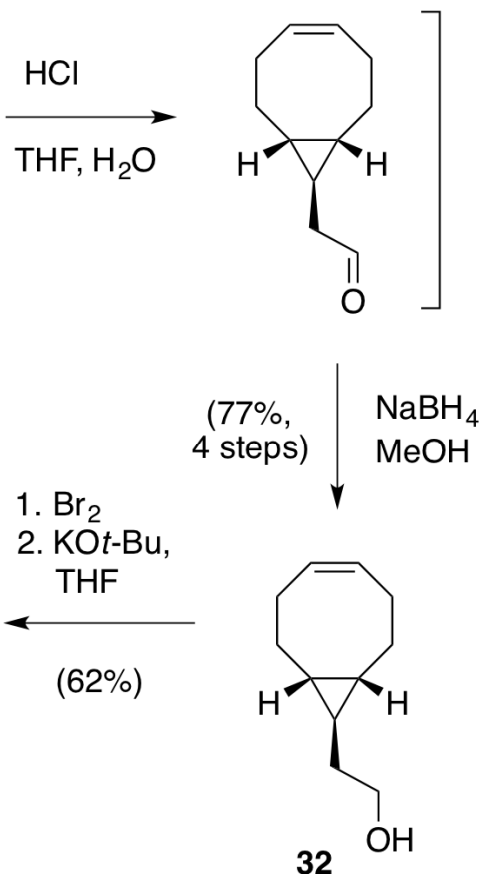

2.1.3. Comparison of BCN-Containing Oligonucleotides to Dibenzofused Cyclooctynes

Now the stage was set to compare the lipophilicity of the oligonucleotides $\mathbf{6}$ and $\mathbf{7}$ containing a BCN-type cyclooctyne to a dibenzoannulated cyclooctyne. To this end, we prepared DBCO-containing hexa-T (compound 8 in Scheme 2) from commercially available DBCO-phosphoramidite. To our satisfaction, C18-reversed phase HPLC analysis confirmed the higher polarity of BCN-containing ONs 
6 and 7 (elution after 13.2 and 12.0 min, respectively) with respect to DBCO-containing ON 8 (19.6 min). The usefulness of BCN-containing ONs for metal-free cycloaddition with azide was also evaluated, by addition of desthiobiotin azide 9 to BCN-charged ON 7 (Figure 2B). HPLC analysis indicated a rapid and quantitative cycloaddition of 6 and 9 (Figures 2C and S1), to give the expected triazole adduct $\mathbf{1 0}$ in only $75 \mathrm{~min}$, thereby corroborating the usefulness of 5'-BCN incorporation for copper-free conjugation of oligonucleotides.

Figure 2. (A) HPLC-reversed phase profile of 6-8. (B) Formation of 10 by SPAAC dimerization of $\mathbf{6}$ and 9. (C) HPLC-traces of conversion of $\mathbf{6}$ into $\mathbf{1 0}$ upon the addition of $\mathbf{9 .}$

(A)

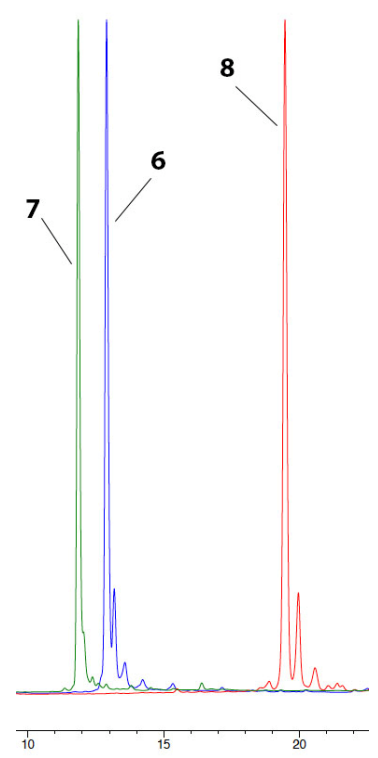

(B)

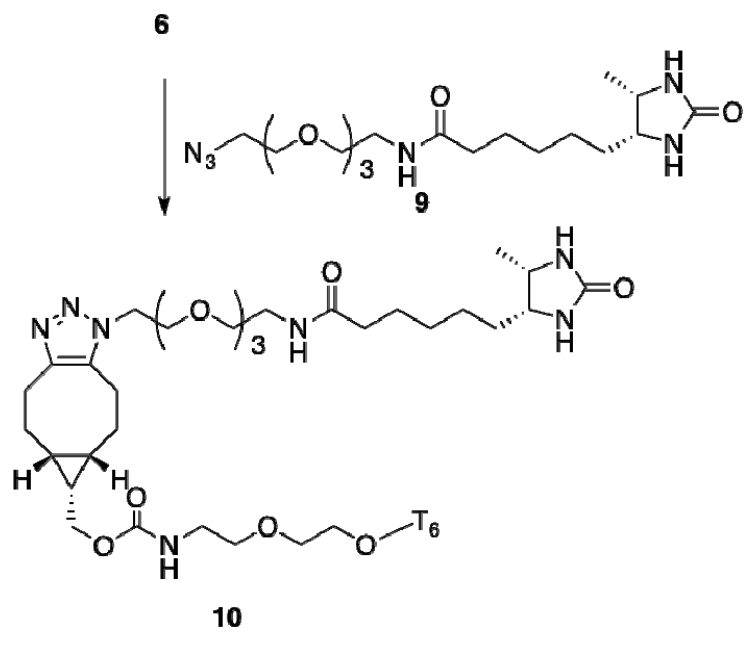

(C)

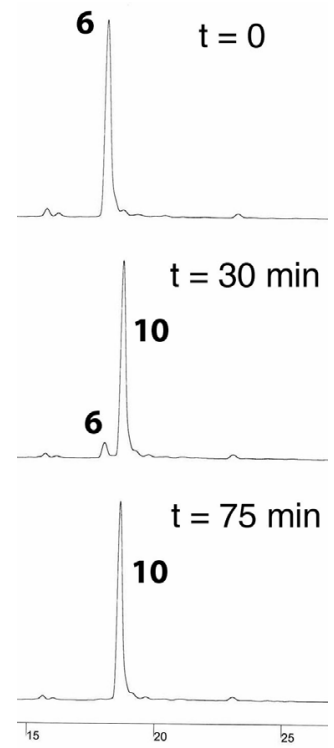

\subsection{3'-Fmoc-Aminopropyl Adenosine for Internal Labeling and Conjugation of Oligonucleotides}

Despite the promising results with $\mathrm{BCN}$-derived phosphoramidites for the preparation of 5 '-functionalized ONs, the introduction of $\mathrm{BCN}$ at other positions in an oligonucleotide ( 3 '-end or internally) is not readily accessible with simple building blocks. Moreover, it is clear that a phosphoramidite-based strategy for the introduction of an azide group, the complementary partner for SPAAC, is hampered by competitive Staudinger reduction of azide with $\mathrm{P}^{\mathrm{III}}$-type reagents [27,31]. Therefore, our next aim was to develop a generic building block for internal incorporation in an ON chain, to facilitate subsequent on-support derivatization with any functional group of choice, including $\mathrm{BCN}$ or azide.

\subsubsection{Preparation, Incorporation and Model Studies}

Based on the above reasoning, a straightforward synthetic route towards Fmoc-protected 2'-O-aminopropyl adenosine-based building block 13 was designed (Scheme 4). Importantly, the $2^{\prime}$-aminopropyl group would ensure subsequent selective functionalization after Fmoc-deprotection. A similar strategy was recently reported based on a 2 '-aminoethyl thymidine building block [25], but to the best of our knowledge on-support oligonucleotide functionalization has not been reported to date. An advantage of modification via $2^{\prime}-\mathrm{OH}$ of ribose, instead of conjugation via the nucleobase, is that 
negligible interference with hybridization is expected, due to the direction of a 2'-O-functional group towards the minor groove of a DNA duplex.

Thus, starting phosphoramidite 13 was conveniently prepared in only three high-yielding steps from readily available 2'-(3-azidopropyl) adenosine building block 11 [38] by Staudinger reduction, Fmoc-protection and phosphitylation (Scheme 4).

Scheme 4. Synthesis of Fmoc-aminopropyl adenosine 13.

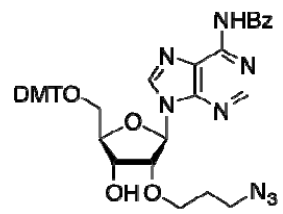

11

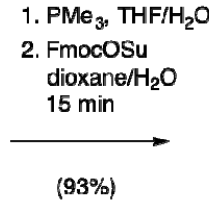

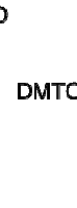

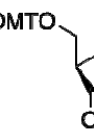
DIPEA, $\mathrm{CH}_{2} \mathrm{Cl}_{2}, 3 \mathrm{~h}$ (91\%)

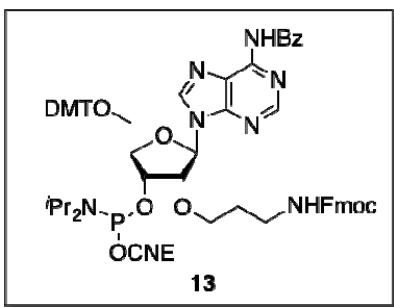

Next, CPG-immobilized thymidine (3) was 5'-chain extended with building block 13 (Scheme 5) under standard conditions. The successful formation of the projected phosphate diester 14 was corroborated by Fmoc removal (20\% piperidine in DMF) to give intermediate 15, followed by cleavage from CPG, leading to the free amino-derivative 16 in high purity, as confirmed by HPLC and HRMS (Figure S2 and Table S1). Alternatively, the Fmoc-deprotected dinucleotide 15 was subjected to on-support acylation before cleavage with $\mathrm{NH}_{4} \mathrm{OH}$, thereby generating a range of DMT-on dinucleotides functionalized with phenylalanine (17), biotin (18) or fluorescein (19). Similarly, intermediate 15 could be smoothly and cleanly converted into BCN-charged carbamate derivative 20, or azide-containing dinucleotide 21.

Scheme 5. On-support incorporation and conjugation of 13 into a dinucleotide.

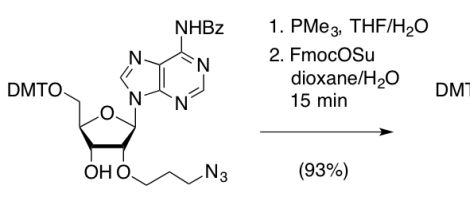

11

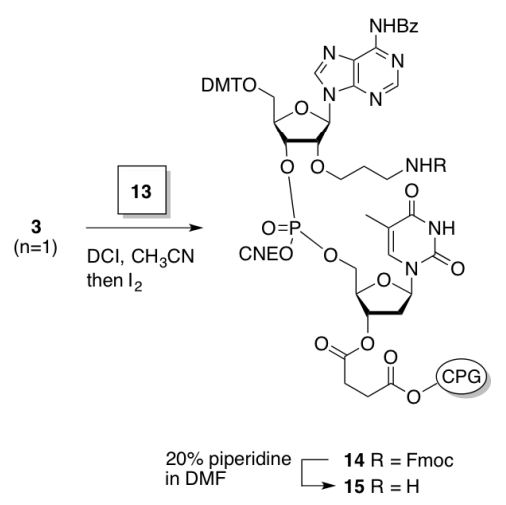

$\underset{\text { DIPEA, } \mathrm{CH}_{2} \mathrm{Cl}_{2}, 3 \mathrm{~h}}{\stackrel{\mathrm{NC}\left(\mathrm{CH}_{2}\right)_{2} \mathrm{OP}\left(\mathrm{Pr}_{2} \mathrm{~N}\right) \mathrm{Cl}}{\longrightarrow}}$

(91\%)

12

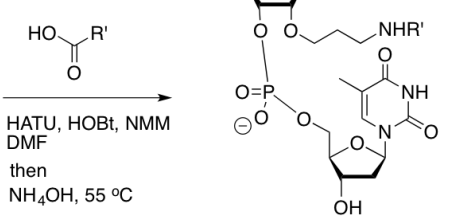

$\mathrm{N}_{3} \sim \mathrm{O} \curvearrowright \mathrm{O} \sim \mathrm{NH}_{2}$

22
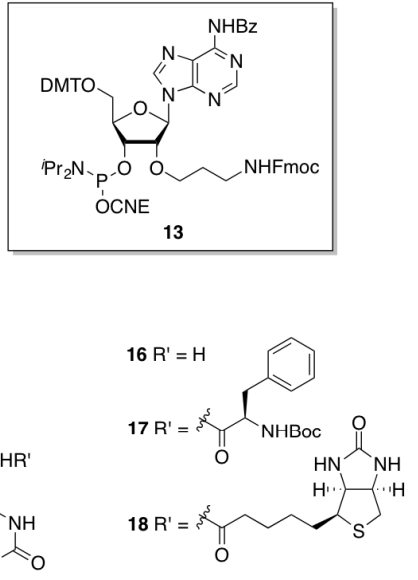

$19 \mathrm{R}^{\prime}={ }_{0}^{5}$ fluorescein

$20 R^{\prime}=$

$21 \mathrm{R}^{\prime}=\overbrace{\mathrm{O}}^{\mathrm{s}} \mathrm{N}_{3}$

The usefulness of the BCN-charged oligonucleotide for follow-up functionalization by SPAAC was in this case corroborated by two experiments. First, treatment of $\mathbf{2 0}$ with excess of 
2-(2-(2-azidoethoxy)ethoxy)ethanamine (22) afforded the anticipated triazole adduct in quantitative yield (Figure S2 and Table S1). A similar smooth reaction was observed for dimerization of BCN-charged dinucleotide $\mathbf{2 0}$ and azide-charged dinucleotide 21, affording exclusively the $(3+2)$ cycloaddition product, as confirmed by HPLC and LC-MS analysis (Figure S2 and Table S1).

\subsubsection{Oligonucleotide Dimerization}

Now the stage was set to evaluate the scope of building block $\mathbf{1 3}$ for the synthesis and functionalization of longer oligonucleotides, and to explore the usefullness of SPAAC to obtain site-specifically conjugated oligonucleotides (Scheme 6). As anticipated, attachment of Fmoc building block 13 to a CPG-tetranucleotide, and subsequent repetitive coupling with standard ON building blocks, proceeded smoothly to give the 12-mer ON 23 with sequence d(AGTATTGX*CCTA) ( $\mathrm{X}^{*}=2^{\prime}$-Fmoc- $N$-propyladenosine), as corroborated by cleavage from CPG of an analytical sample. Next, undecanucleotide 23 was on-support Fmoc-deprotected with piperidine (to 24) and coupled with azidohexanoic acid or a BCN-derived active carbonate and cleaved from support, to give the respective azide derivative 25 and $\mathrm{BCN}$-derivative 26, respectively. As anticipated, overnight stirring of a 1:1 mixture of the BCN- and the azide-functionalized $\mathrm{ON}$ conjugates $\mathbf{2 6}$ and $\mathbf{2 5}$, respectively, was found to give the desired oligonucleotide dimer 27, as confirmed by HPLC and MALDI-TOF analysis (Table S2), thereby demonstrating for the versatility of our approach for conjugation of oligonucleotides at any adenosine in the ribose backbone.

Scheme 6. On-support preparation of azide or BCN-charged oligonucleotides and dimerization in solution.

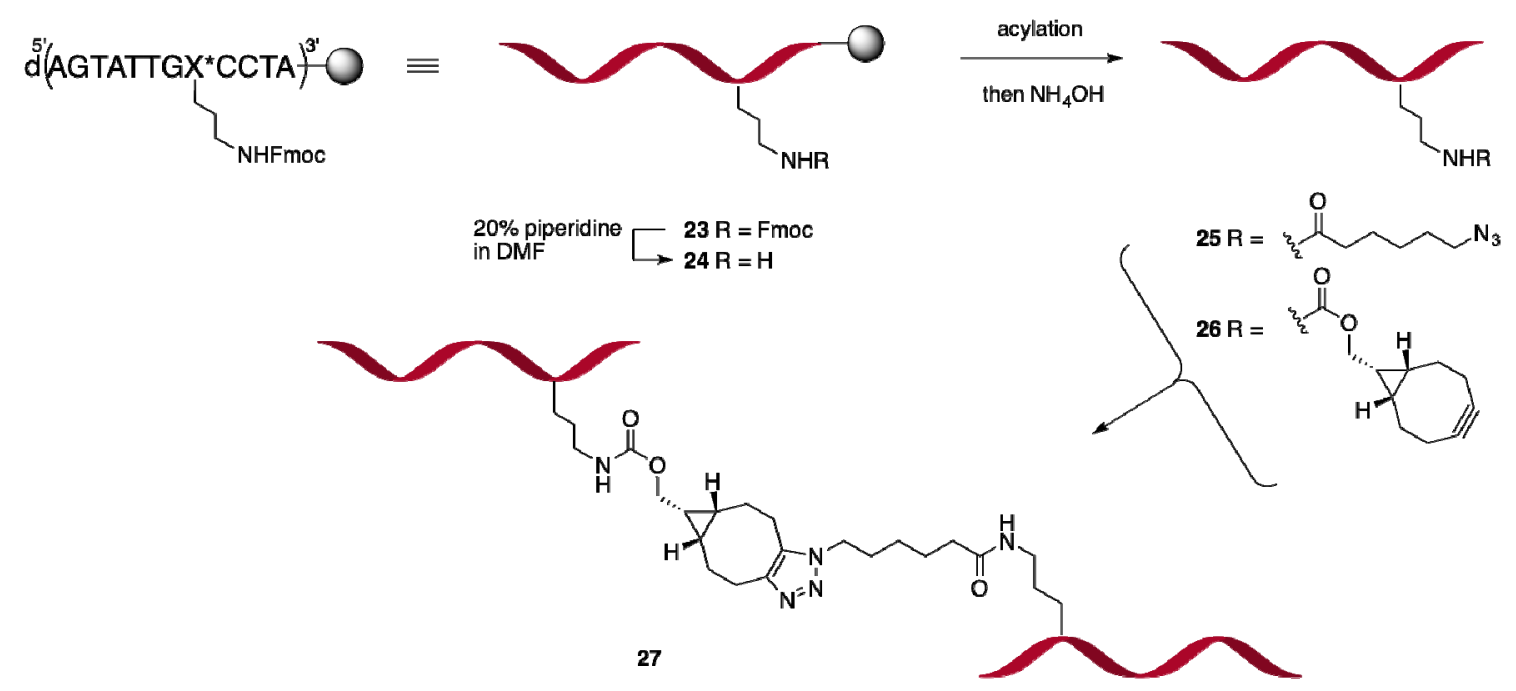

\subsubsection{Oligonucleotide-Polythiophene Hybrid}

Finally, we were intrigued by the idea of applying SPAAC for the synthesis of functional oligonucleotide-containing materials, in particular toward the construction of bioresponsive films. Poly(3-hexylthiophene) (P3HT) is a well known electroconductive material which can be found in solar cells and other nanoelectronic devices but is known to be notoriously insoluble in aqueous systems. One potential strategy for solubilization would involve attachment of oligonucleotides to 
these synthetic lipophilic polymers. To this end, azido-functionalized P3HT (28) was treated with BCN-conjugated ON 5'-d(AGTATTGXCCTA)-3' (26) and the reaction was monitored by color change as well as UV-VIS spectroscopy (Figure 3). To our satisfaction, mixing 28 and $\mathbf{2 6}$ led to the formation of a yellowish solution, thereby indicating the formation of composites through $(3+2)$ cycloaddition between $\mathrm{P} 3 \mathrm{HT}$ and $\mathrm{ON}$ as the result of the slow solubilization of the otherwise completely water-insoluble hydrophobic polymer 28. More conclusive support for succesfull conjugation was obtained by UV-VIS spectroscopy, which clearly revealed the presence of P3HT in the aqueous solution as indicated by the appearance of absorption peak at $455 \mathrm{~nm}$ (Figure 3C), as well as by MALDI-TOF analysis (Figure S4).

Figure 3. (A) Conjugation of azido-terminated P3HT 28 and BCN-containing oligonucleotide 26 leading to 29. (B) Aqueous solution of 28 turns yellow as a consequence of spontaneous $(3+2)$ cycloaddition leading to solubilization. (C) UV-VIS spectrum of aqueous solution shows the appearance of the typical absorption band of P3HT at $455 \mathrm{~nm}$.

(A)

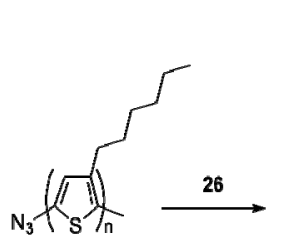

28

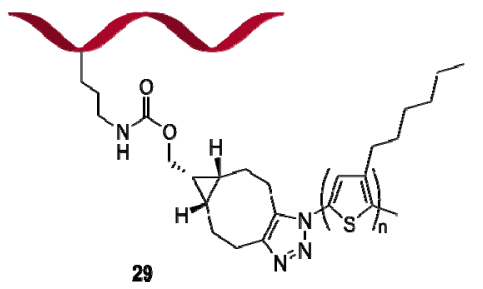

(B)

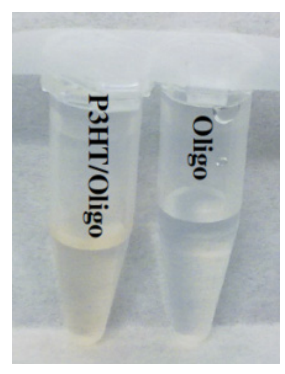

(C)

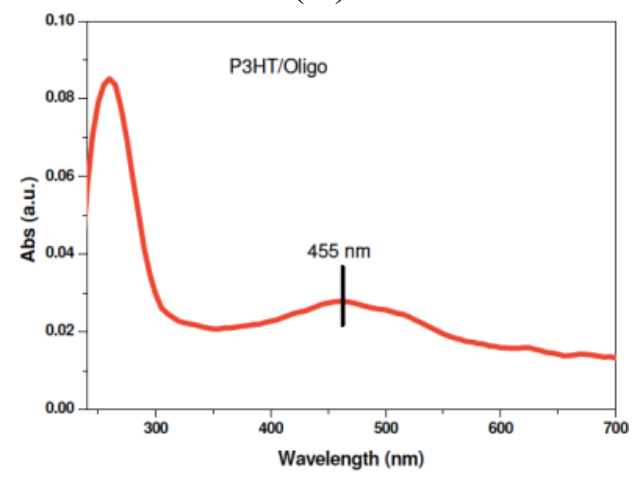

\section{Experimental}

${ }^{1} \mathrm{H}-\mathrm{NMR}$ spectra were recorded on Bruker DMX 300 or Varian Inova-400 spectrometers at $300 \mathrm{~K}$. TMS $\left(\delta_{\mathrm{H}} 0.00\right)$ or $\mathrm{CD}_{3} \mathrm{CN}\left(\delta_{\mathrm{H}} 1.94\right)$ was used as the internal reference. ${ }^{13} \mathrm{C}-\mathrm{NMR}$ spectra were recorded in $\mathrm{CDCl}_{3}$ at $75 \mathrm{MHz}$ on a Bruker DMX 300 spectrometer, using the central resonance of $\mathrm{CDCl}_{3}\left(\delta_{\mathrm{C}} 77.0\right)$ as the internal reference. ${ }^{31} \mathrm{P}$ NMR and ${ }^{1} \mathrm{H}-\mathrm{NMR}$ spectra for $\mathbf{1}, \mathbf{2}$ and $\mathbf{V}$ were provided by NuMega Resonance Labs. Mass spectra were obtained on Applied Biosystems Voyager DE-Pro MALDI-TOF (no calibration) or JEOL AccuToF. Identities of 4, 5, 6, 7, 8, and 10 were confirmed by MS or LCMS that were provided by Novatia, LLC. Except as specified below, chemicals were purchased from Aldrich Chemical Co. and used without further purification. $\mathrm{CH}_{2} \mathrm{Cl}_{2}$, acetonitrile, THF, $\mathrm{Et}_{2} \mathrm{O}$ and toluene were obtained dry from a MBRAUN SPS-800 solvent purification system; and $\mathrm{CH}_{3} \mathrm{OH}$ was distilled from magnesium and iodine. Aqueous solutions are saturated unless otherwise specified. All reactions were performed under anhydrous conditions under argon and monitored by TLC on Kieselgel 60 F254 (Merck, Darmstadt, Germany). Prior to analysis of phosphoramidites, TLC plates were buffered by dipping in $2 \% \mathrm{Et}_{3} \mathrm{~N}$ in hexanes and air dried. Detection was by examination under UV light $\left(254 \mathrm{~nm}\right.$ ) and by charring with $10 \%$ sulfuric acid in methanol, with aqueous $\mathrm{KMnO}_{4}$, or ethanolic phosphomolybdic acid (PMA). Silica gel (Acros 0.035-0.070 mm, and for 
phosphoramidites, SiliCycle, $0.060-0.200 \mathrm{~mm})$ was used for chromatography. $\left(i-\mathrm{Pr}_{2} \mathrm{~N}\right)_{2} \mathrm{POCH}_{2} \mathrm{CH}_{2} \mathrm{CN}$ was obtained from Digital Specialty Chemicals, catalog \# 269 (2-Cyanoethyl $N, N, N^{\prime} N^{\prime}-$ tetraisopropylphosphorodiamidite). Compound 9 was provided by Berry and Associates, Inc., catalog \# BT 1075 (Desthiobiotin-TEG azide). DBCO-phosphoramidite was obtained from Glen Research Corp., catalog \#10-1941 (5'-DBCO-TEG phosphoramidite).

Automated ON synthesis was completed using a Millipore Expedite (8900 series) nucleic acid synthesis system using the recommended thymidine conditions for each synthesis cycle in a DMT-on protocol for $0.2 \mathrm{Mol}$ columns. Standard synthesizer reagents and thymidine-CPG were obtained from Glen Research Corporation. The ONs were deprotected and cleaved from the CPG support by manually passing conc. $\mathrm{NH}_{4} \mathrm{OH}$ back and forth through the column with a pair of syringes for 15 min. The resulting $\mathrm{ON}$ solutions were sparged with $\mathrm{N}_{2}$ for 3 hours to remove excess $\mathrm{NH}_{3}$. The concentrated solutions were frozen and lyophilized.

2-(endo-Bicyclo[6.1.0]non-4-yn-9-yl)methyl (2-cyanoethyl) diisopropylphosphoramidite (1) Endo-BCNmethanol $(1.00 \mathrm{~g}, 6.66 \mathrm{mmol})$ was dissolved in anhydrous $\mathrm{CH}_{2} \mathrm{Cl}_{2}(17 \mathrm{~mL})$ and treated with $\left(i-\mathrm{Pr}_{2} \mathrm{~N}\right)_{2} \mathrm{POCH}_{2} \mathrm{CH}_{2} \mathrm{CN}(2.43 \mathrm{~mL}, 7.66 \mathrm{mmol})$. A solution of $\mathrm{CF}_{3} \mathrm{CO}_{2} \mathrm{H}(0.25 \mathrm{M})$ and 1-methylimidazole $(0.50 \mathrm{M})$ in anhydrous $\mathrm{CH}_{2} \mathrm{Cl}_{2}(13.3 \mathrm{~mL})$ was added dropwise then the reaction was stirred at $\mathrm{RT}$ for 90 min. TLC (hexane-acetone, 90:10, PMA stain) shows the complete consumption of endo-BCN-methanol (Rf 0.40) and the appearance of a single new product ( $\mathrm{Rf} 0.68$ ). The reaction mixture was partitioned between $\mathrm{CH}_{2} \mathrm{Cl}_{2}(50 \mathrm{~mL})$ and $\mathrm{H}_{2} \mathrm{O}(50 \mathrm{~mL})$. The organic layer was washed with $\mathrm{H}_{2} \mathrm{O}(50 \mathrm{~mL})$ and saturated $\mathrm{NaHCO}_{3}(35 \mathrm{~mL})$. The organic layer was dried over $\mathrm{Na}_{2} \mathrm{SO}_{4}$, filtered and concentrated at reduced pressure. Silica $(36 \mathrm{~g})$ was slurried in hexane- $\mathrm{Et}_{3} \mathrm{~N}(95: 5,85 \mathrm{~mL})$ and packed into a $60 \mathrm{~mL}$ sintered glass funnel. The bed of silica was eluted with hexanes $(50 \mathrm{~mL})$ before a solution of crude product in hexanes (7 mL) was applied. Elution with hexane-acetone (96:4), collecting $30 \mathrm{~mL}$ fractions affords purified 1 $(1.88 \mathrm{~g}, 80.6 \%)$ after evaporation of solvent and drying under vacuum overnight. ${ }^{1} \mathrm{H}-\mathrm{NMR}(500 \mathrm{MHz}$, $\mathrm{CD}_{3} \mathrm{CN}$ ) $\delta 3.82-3.67(\mathrm{~m}, 4 \mathrm{H}), 3.65-3.55(\mathrm{~m}, 2 \mathrm{H}), 2.62$ (q, 2H), 2.29-2.18 (m, 6H), $2.14(\mathrm{~s}, 2 \mathrm{H}), 1.35-1.27$ (m, 1H), 1.17 (d, 12H), 0.90-0.82 (2H). ${ }^{31} \mathrm{P}$ NMR (500 MHz, $\left.\mathrm{CD}_{3} \mathrm{CN}\right) \delta 147.64$ (s, 98.6\%). MS (AP+): $351(\mathrm{M}+\mathrm{H}) ; 373(\mathrm{M}+\mathrm{Na})$.

endo-Bicyclo[6.1.0]non-4-yn-9-ylmethyl (2-(2-hydroxyethoxy)ethyl)carbamate Under an atmosphere of argon, BCN (1.80 g; $12.0 \mathrm{mmol})$ was dissolved in $100 \mathrm{~mL}$ anhydrous $\mathrm{MeCN}$, and disuccinimidylcarbonate $(3.38 \mathrm{~g} ; 13.2 \mathrm{mmol})$ and triethylamine $(5.0 \mathrm{~mL} ; 3.64 \mathrm{mmol} ; 36.0 \mathrm{mmol})$ were added. The resulting mixture was stirred for $2.5 \mathrm{~h}$ and concentrated. The residue was taken up in diethyl ether $(100 \mathrm{~mL})$ and washed with a saturated aqueous solution of $\mathrm{NH}_{4} \mathrm{Cl}$. After separation, the organic layer was dried $\left(\mathrm{Na}_{2} \mathrm{SO}_{4}\right)$ and concentrated. The residue was taken up in DCM $(100 \mathrm{~mL})$, washed with water $(50 \mathrm{~mL})$, dried $\left(\mathrm{Na}_{2} \mathrm{SO}_{4}\right)$ and concentrated. The residue was taken up in EtOAc $(50 \mathrm{~mL})$ and concentrated. Crude carbonate: $3.08 \mathrm{~g}$.

The crude residue $(2.5 \mathrm{~g}$, max $8.6 \mathrm{mmol})$ was dissolved in DCM $(100 \mathrm{~mL})$ under an atmosphere of argon. 2-(2-Aminoethoxy)ethanol $(1.0 \mathrm{~mL} ; 1.1 \mathrm{~g} ; 10.3 \mathrm{mmol})$ and triethylamine $(3.6 \mathrm{~mL}: 2.6 \mathrm{~g}$; $25.8 \mathrm{mmol}$ ) were added and the resulting mixture was stirred for $15 \mathrm{~min}$. After concentration, the residue was purified by column chromatography (EtOAc/pentane 3/1). The pure fractions were combined, concentrated, taken up in EtOAc, filtered and concentrated. Yield over two steps: $1.48 \mathrm{~g}$ 
(5.26 mmol; 54\%). ${ }^{1} \mathrm{H}-\mathrm{NMR}\left(\mathrm{CDCl}_{3}, 300 \mathrm{MHz}\right): \delta(\mathrm{ppm}) 5.04(\mathrm{bs}, 1 \mathrm{H}), 4.16(\mathrm{~d}, \mathrm{~J}=8.1 \mathrm{~Hz}, 2 \mathrm{H})$, 3.79-3.70 (m, 2H), 3.62-3.54 (m, 2H), $3.40(\mathrm{dd}, \mathrm{J}=10.7 \mathrm{~Hz}, 5.4 \mathrm{~Hz}), 2.37-2.12(\mathrm{~m}, 6 \mathrm{H}), 2.01$ (bs, 1H), 1.70-1.48 (m, 2H), 1.43-1.30 (m, 1H), 1.02-0.87 (m, 2H).

endo-Bicyclo[6.1.0]non-4-yn-9-ylmethyl(2-(2-(((2-cyanoethoxy)(diisopropylamino)-phosphino)oxy) ethoxy)ethyl)carbamate (2) Endo-bicyclo[6.1.0]non-4-yn-9-ylmethyl (2-(2-hydroxyethoxy)ethyl) carbamate $(5.00 \mathrm{~g}, 17.8 \mathrm{mmol})$ was dissolved in anhydrous $\mathrm{CH}_{2} \mathrm{Cl}_{2}(65 \mathrm{~mL})$ and treated with $\left(i-\mathrm{Pr}_{2} \mathrm{~N}\right)_{2} \mathrm{POCH}_{2} \mathrm{CH}_{2} \mathrm{CN}(6.49 \mathrm{~mL}, 20.4 \mathrm{mmol})$. A solution of $\mathrm{CF}_{3} \mathrm{CO}_{2} \mathrm{H}(0.25 \mathrm{M})$ and 1-methylimidazole $(0.50 \mathrm{M})$ in anhydrous $\mathrm{CH}_{2} \mathrm{Cl}_{2}(35.5 \mathrm{~mL})$ was added dropwise then the reaction was stirred at $\mathrm{RT}$ for 90 min. TLC (hexane-acetone, 80:20, PMA stain) shows the complete consumption of starting material (Rf 0.15) and the appearance of a single new product ( $\mathrm{Rf} 0.50$ ). The reaction mixture was partitioned between $\mathrm{CH}_{2} \mathrm{Cl}_{2}(50 \mathrm{~mL})$ and $\mathrm{H}_{2} \mathrm{O}(150 \mathrm{~mL})$. The organic layer was washed with $\mathrm{H}_{2} \mathrm{O}(150 \mathrm{~mL})$ and $5 \% \mathrm{NaHCO}_{3}(150 \mathrm{~mL})$. The organic layer was dried over $\mathrm{Na}_{2} \mathrm{SO}_{4}$, filtered and concentrated at reduced pressure. Silica $(130 \mathrm{~g})$ was slurried in hexane-acetone- $\mathrm{Et}_{3} \mathrm{~N}(95: 5: 5,250 \mathrm{~mL})$ and packed into a $5 \mathrm{~cm}$ diameter column. The crude product was dissolved in $\mathrm{CH}_{2} \mathrm{Cl}_{2}(8 \mathrm{~mL})$ and diluted with hexanes $(12 \mathrm{~mL})$ and the cloudy solution was applied to the column. Initial elution was performed with hexaneacetone- $\mathrm{CH}_{2} \mathrm{Cl}_{2}-\mathrm{Et}_{3} \mathrm{~N}$ (79.5:10:10:0.5, $100 \mathrm{~mL}$ ). Subsequent elution was performed with HexaneAcetone- $\mathrm{Et}_{3} \mathrm{~N}$ (85.5:14:0.5), collecting $75 \mathrm{~mL}$ fractions. Pure product fractions were combined and concentrated at reduced pressure. The resulting colorless liquid was re-dissolved in $\mathrm{CH}_{2} \mathrm{Cl}_{2}(50 \mathrm{~mL})$ and concentrated again. Further drying overnight under vacuum affords purified 2 (6.86 g, 80\%). ${ }^{1} \mathrm{H}-\mathrm{NMR}\left(500 \mathrm{MHz}, \mathrm{CD}_{3} \mathrm{CN}\right) \delta 5.17(\mathrm{~s}, 1 \mathrm{H}), 4.13(\mathrm{~d}, 2 \mathrm{H}), 3.82-3.51(\mathrm{~m}, 8 \mathrm{H}), 3.38-3.26(\mathrm{~m}, 2 \mathrm{H}), 2.64$ $(\mathrm{q}, 2 \mathrm{H}), 2.29-2.18(\mathrm{~m}, 6 \mathrm{H}), 2.14(\mathrm{~s}, 2 \mathrm{H}), 1.38-1.22(\mathrm{~m}, 1 \mathrm{H}), 1.17(\mathrm{~d}, 12 \mathrm{H}), 0.88-0.84(2 \mathrm{H}) .{ }^{31} \mathrm{P}$ NMR $\left(500 \mathrm{MHz}, \mathrm{CD}_{3} \mathrm{CN}\right) \delta 149.11(\mathrm{~s}, 100 \%)$. MS (AP+): $482(\mathrm{M}+\mathrm{H}) ; 504(\mathrm{M}+\mathrm{Na})$.

(Z)-exo-Bicyclo[6.1.0]non-4-ene-9-carbaldehyde (31) (Z)-exo-Bicyclo[6.1.0]non-4-en-9-ylmethanol (30) (5.2 g, $26.6 \mathrm{mmol})$ was dissolved in DCM (300 mL). Pyridinium chlorochromate (10.5 g, $48.5 \mathrm{mmol}$ ) was added. The resulting reaction mixture was stirred for $2 \mathrm{~h}$ and subsequently filtered over a short path of silica gel. The filtrate was concentrated and purified by column chromatography (DCM), yielding $4.95 \mathrm{~g}$ of the aldehyde (B). ${ }^{1} \mathrm{H} \mathrm{NMR}\left(300 \mathrm{MHz}, \mathrm{CDCl}_{3}\right) \delta(\mathrm{ppm}) 9.04(\mathrm{~d}, J=5.5 \mathrm{~Hz}$, 1H), 5.71-5.58 (m, 2H), 2.49-2.01 (m, 6H), 1.77-1.44 (m, 5H).

(Z)-exo-2-(Bicyclo[6.1.0]non-4-en-9-yl)ethanol (32) Under an atmosphere of argon (methoxymethyl)triphenylphosphonium chloride $(17.1 \mathrm{~g} ; 50 \mathrm{mmol})$ was suspended in anhydrous THF $(100 \mathrm{~mL})$ and cooled to $0{ }^{\circ} \mathrm{C}$. Potassium tert-butoxide $(5.6 \mathrm{~g} ; 50 \mathrm{mmol})$ was added and the resulting mixture was stirred for $20 \mathrm{~min}$. A solution of $31(4.95 \mathrm{~g}, 33.0 \mathrm{mmol})$ in anhydrous THF $(100 \mathrm{~mL})$ was added. The resulting reaction mixture was stirred for $15 \mathrm{~min}$ and then poured into a mixture of diethyl ether and water $(200 \mathrm{~mL} / 200 \mathrm{~mL})$. The aqueous phase was separated and extracted a second time with diethyl ether $(100 \mathrm{~mL})$. The two combined organic layers were dried $\left(\mathrm{Na}_{2} \mathrm{SO}_{4}\right)$ and concentrated at reduced pressure. The residue was dissolved in THF $(200 \mathrm{~mL})$ and aqueous hydrochloric acid $(1 \mathrm{M}, 100 \mathrm{~mL})$ was added. The resulting mixture was heated to reflux for $45 \mathrm{~min}$, cooled to room temperature and poured into a mixture of diethyl ether and water $(200 \mathrm{~mL} / 200 \mathrm{~mL})$. The aqueous phase was separated and extracted a second time with diethyl ether $(100 \mathrm{~mL})$. The two combined organic layers were dried 
$\left(\mathrm{Na}_{2} \mathrm{SO}_{4}\right)$ and concentrated at reduced pressure. The residue was dissolved in methanol $(200 \mathrm{~mL})$ and placed under an atmosphere of argon. After cooling the reaction mixture to $0^{\circ} \mathrm{C}, \mathrm{NaBH}_{4}(1.89 \mathrm{~g}$; $50 \mathrm{mmol}$ ) was added in portions. The mixture was stirred for $15 \mathrm{~min}$, quenched with saturated aqueous ammonium chloride $(100 \mathrm{~mL})$ and partitioned between diethyl ether $(200 \mathrm{~mL})$ and water $(100 \mathrm{~mL})$. The aqueous phase was separated and extracted with diethyl ether $(2 \times 200 \mathrm{~mL})$. The three combined organic layers were dried $\left(\mathrm{Na}_{2} \mathrm{SO}_{4}\right)$ and concentrated at reduced pressure. The crude product was purified by column chromatography on silica gel, eluting with a $10-25 \%$ gradient of ethylacetate in pentane to provide $4.22 \mathrm{~g}(77 \%)$ of 32. ${ }^{1} \mathrm{H} \mathrm{NMR}\left(300 \mathrm{MHz}, \mathrm{CDCl}_{3}\right) \delta 5.70-5.56(\mathrm{~m}, 2 \mathrm{H}), 3.68(\mathrm{t}$, $J=6.6 \mathrm{~Hz}, 2 \mathrm{H}), 2.39-1.94(\mathrm{~m}, 6 \mathrm{H}), 1.51$ (q, $J=6.7 \mathrm{~Hz}, 2 \mathrm{H}), 1.44-1.23(\mathrm{~m}, 3 \mathrm{H}), 0.71-0.57$ (m, 2H), $0.30-0.20(\mathrm{~m}, 2 \mathrm{H})$.

Exo-BCN-ethanol (33) A solution of bromine $(1.37 \mathrm{~mL}, 26.7 \mathrm{mmol})$ in dichloromethane $(25 \mathrm{~mL})$ was added dropwise to an ice-cold solution of $32(4.22 \mathrm{~g}, 25.4 \mathrm{mmol})$ in dichloromethane (100 $\mathrm{mL})$. Subsequently, $10 \%$ aqueous $\mathrm{Na}_{2} \mathrm{~S}_{2} \mathrm{O}_{3}(50 \mathrm{~mL})$ is added. The aqueous phase was separated and extracted a second time with dichloromethane $(50 \mathrm{~mL})$. The two combined organic layers were dried $\left(\mathrm{Na}_{2} \mathrm{SO}_{4}\right)$ and concentrated at reduce pressure to afford dibromide (8.33 g, quant.). Without further purification, the crude intermediate was dissolved in anhydrous THF $(100 \mathrm{~mL})$, placed under an argon atmosphere, and cooled to $0^{\circ} \mathrm{C}$. A solution of potassium tert-butoxide $(9.3 \mathrm{~g} ; 83 \mathrm{mmol})$ in anhydrous THF $(100 \mathrm{~mL})$ was added dropwise. The resulting reaction mixture was heated to $70{ }^{\circ} \mathrm{C}$, stirred for $30 \mathrm{~min}$, and quenched with a saturated aqueous solutiono of $\mathrm{NH}_{4} \mathrm{Cl}(100 \mathrm{~mL})$. The resulting mixture was extracted twice with diethyl ether $(200 \mathrm{~mL})$. The two combined organic layers were then dried $\left(\mathrm{Na}_{2} \mathrm{SO}_{4}\right)$ and concentrated at reduced pressure. The crude product was purified chromatography on silica gel to afford exo-BCN-ethanol (33) $(2.57 \mathrm{~g} ; 15.6 \mathrm{mmol} ; 62 \%)$ as a slightly yellow solid/wax. ${ }^{1} \mathrm{H}$ NMR (300 MHz, $\left.\mathrm{CDCl}_{3}\right) \delta(\mathrm{ppm}) 3.71(\mathrm{t}, J=6.5 \mathrm{~Hz}, 2 \mathrm{H}), 2.46-2.07(\mathrm{~m}, 6 \mathrm{H}), 1.63-1.54(\mathrm{~m}, 2 \mathrm{H})$, $1.44-1.22(\mathrm{~m}, 3 \mathrm{H}), 0.63-0.46(\mathrm{~m}, 2 \mathrm{H}), 0.34-0.22(\mathrm{~m}, 1 \mathrm{H}) .{ }^{13} \mathrm{C} \mathrm{NMR}\left(300 \mathrm{MHz}, \mathrm{CDCl}_{3}\right) \delta(\mathrm{ppm}) 99.6$, 63.0, 49.0, 38.6, 34.9, 25.6, 22.8, 22.1. $\left(\mathrm{ESI}^{+}\right)$: calculated for $\mathrm{C}_{11} \mathrm{H}_{16} \mathrm{O}: 164.1201$, found 164.1186.

exo-Bicyclo[6.1.0]non-4-yn-9-ylmethyl (2-(2-(((2-cyanoethoxy)(diisopropyl-amino)phosphino)-oxy)ethoxy)ethyl)carbamate (34) Exo-BCN-ethanol $33(2.00 \mathrm{~g}, 12.2 \mathrm{mmol})$ was dissolved in anhydrous $\mathrm{CH}_{2} \mathrm{Cl}_{2}(30 \mathrm{~mL})$ and treated with $\left(i-\mathrm{Pr}_{2} \mathrm{~N}\right)_{2} \mathrm{POCH}_{2} \mathrm{CH}_{2} \mathrm{CN}(4.50 \mathrm{~mL}, 14.1 \mathrm{mmol})$. A solution of $\mathrm{CF}_{3} \mathrm{CO}_{2} \mathrm{H}(0.25 \mathrm{M})$ and 1-methylimidazole $(0.50 \mathrm{M})$ in anhydrous $\mathrm{CH}_{2} \mathrm{Cl}_{2}(25.0 \mathrm{~mL})$ was added dropwise, then the reaction was stirred at RT for $3 \mathrm{hr}$. TLC (hexane-acetone, 90:10, PMA stain) shows the complete consumption of exo-BCN-ethanol ( $\mathrm{Rf} 0.25$ ) and the appearance of a single new product (Rf 0.70). The reaction mixture was partitioned between $\mathrm{CH}_{2} \mathrm{Cl}_{2}(50 \mathrm{~mL})$ and $\mathrm{H}_{2} \mathrm{O}(100 \mathrm{~mL})$. The organic layer was washed with $\mathrm{H}_{2} \mathrm{O}(100 \mathrm{~mL})$ and saturated $\mathrm{NaHCO}_{3}(50 \mathrm{~mL})$. The organic layer was dried over $\mathrm{Na}_{2} \mathrm{SO}_{4}$, filtered and concentrated at reduced pressure. Silica $(70 \mathrm{~g})$ was slurried in hexane-Et $3 \mathrm{~N}(95: 5,170 \mathrm{~mL})$ and packed into a $5 \mathrm{~cm}$ diameter column. The silica column was eluted with hexanes $(80 \mathrm{~mL})$ before a solution of crude product in hexanes $(13 \mathrm{~mL})$ was applied. Elution with hexane-acetone (97:3), collecting $50 \mathrm{~mL}$ fractions affords purified 34 (3.50 g, 79\%) after evaporation of solvent and drying under vacuum for $48 \mathrm{~h} .{ }^{31} \mathrm{P}$ NMR (500 MHz, $\left.\mathrm{CD}_{3} \mathrm{CN}\right) \delta 147.39$ (s, 100\%). MS $(\mathrm{AP}+): 365(\mathrm{M}+\mathrm{H}) ; 387(\mathrm{M}+\mathrm{Na})$. 


\section{HPLC-analysis of 6, 7 and 8}

The lyophilized ONs were each dissolved in $0.1 \mathrm{M} \mathrm{Et}_{3} \mathrm{~N} . \mathrm{HOAc}-\mathrm{MeCN}(95: 5,3 \mathrm{~mL})$ for analysis by reversed phase HPLC analysis: Stationary phase, Supelco $5 \mathrm{M} \mathrm{C}-18(150 \times 4.6 \mathrm{~mm})$; Mobile phase gradient 10\%-35\% MeCN in 0.1M TEAA over 25 minutes; Elution $1.0 \mathrm{~mL} / \mathrm{min}$; Detection $254 \mathrm{~nm}$.

\section{SPAAC reaction of 6 and 9}

Oligonucleotide 6 (lyophilized product from a 0.2 mol column) was dissolved in $0.1 \mathrm{M}$ $\mathrm{Et}_{3} \mathrm{~N} . \mathrm{HOAc} / \mathrm{MeCN}(90: 10, \mathrm{v} / \mathrm{v}, 0.8 \mathrm{~mL})$. This solution was passed through a $0.2 \mathrm{M}$ PTFE filter into a concentrated solution of 9 ( $2 \mathrm{mg}, 4.8 \mathrm{~mol}, \sim 25$ equivalents, dissolved in $60 \mathrm{~L} \mathrm{MeCN})$. The progress of the SPAAC reaction was monitored by reversed phase HPLC on a $\mathrm{C}_{18}$ column $(150 \times 4.6 \mathrm{~mm})$, eluting at $1.0 \mathrm{~mL} / \mathrm{min}$ with a gradient of $5 \%-35 \% \mathrm{MeCN}$ in $0.1 \mathrm{M} \mathrm{Et}_{3} \mathrm{~N} . \mathrm{HOAc}$ over $30 \mathrm{~min}$, recording UV absorption at $260 \mathrm{nM}$. Excess 9 does not absorb at this wavelength and, therefore, only $\mathbf{6}$ and $\mathbf{1 0}$ are visible in the chromatograms. Mass spectral analysis of the major peak corroborated the expected formation of product 10. MS (AP+): $2521.2(\mathrm{M}+\mathrm{H})$.

5'-O-(4,4'-Dimethoxytriphenylmethyl)-2'-O-(9H-fluoren-9-yl-methylcarbonyl)-aminoprop-1-yl-6-Nbenzoyladenosine (12) To the solution of 5'-O-(4,4'-dimethoxytriphenylmethyl)-2'-O-azidoprop-1-yl6- $N$-benzoyladenosine 11 (750 mg, $0.99 \mathrm{mmol})$ in $\mathrm{THF} / \mathrm{H}_{2} \mathrm{O}(2: 1)(18 \mathrm{~mL})$, trimethylphosphine $(1.5 \mathrm{~mL}, 1.5 \mathrm{mmol})$ was added. Reaction stirred at $\mathrm{rt}$ for $8 \mathrm{~h}$ and evaporated to dryness. The residue was taken into Dioxane $/ \mathrm{H}_{2} \mathrm{O}(1: 1)(20 \mathrm{~mL}), \mathrm{NaHCO}_{3}(185 \mathrm{mg}, 2.2 \mathrm{mmol})$ was added. The reaction mixture was cooled down to $0{ }^{\circ} \mathrm{C}$, Fmoc-OSu $(415 \mathrm{mg}, 1.23 \mathrm{mmol})$ in dioxane $(2 \mathrm{~mL})$ was added drop wise and stirred for $15 \mathrm{~min}$ at $0{ }^{\circ} \mathrm{C}$. The reaction was quenched with water, extracted with $\mathrm{CH}_{2} \mathrm{Cl}_{2}$ $(3 \times 20 \mathrm{~mL})$, the combined organic layer was dried over $\mathrm{Na}_{2} \mathrm{SO}_{4}$ and concentrated to dryness. Flash-chromatography $\left(\mathrm{CH}_{2} \mathrm{Cl}_{2}\right.$ /acetone, 6:4, v/v), gave the desired compound $(850 \mathrm{mg}, 90 \%)$ as a colorless foam. ${ }^{1} \mathrm{H}-\mathrm{NMR}(400 \mathrm{MHz}, \mathrm{DMSO}) \delta 11.23(\mathrm{~s}, 1 \mathrm{H}), 8.68(\mathrm{~s}, 1 \mathrm{H}), 8.62(\mathrm{~s}, 1 \mathrm{H}), 8.06(\mathrm{~d}$, $J=7.2 \mathrm{~Hz}, 2 \mathrm{H}), 7.87(\mathrm{~d}, J=7.2 \mathrm{~Hz}, 2 \mathrm{H}), 7.66(\mathrm{~m}, 3 \mathrm{H}), 7.57(\mathrm{~m}, 2 \mathrm{H}), 7.39-7.18(\mathrm{~m}, 14 \mathrm{H}), 6.85$ (m, $4 \mathrm{H}), 6.19(\mathrm{~d}, J=4.8 \mathrm{~Hz}, 1 \mathrm{H}), 4.65(\mathrm{~m}, 1 \mathrm{H}), 4.48(\mathrm{~m}, 1 \mathrm{H}), 4.28(\mathrm{~d}, J=6.8 \mathrm{~Hz}, 2 \mathrm{H}), 3.71(\mathrm{~s}, 3 \mathrm{H})$, 3.65-3.53 (m, 2H), 3.27 (m, 2H), $3.26(\mathrm{~m}, 2 \mathrm{H}), 1.66(\mathrm{~m}, 2 \mathrm{H}) .{ }^{13} \mathrm{C}-\mathrm{NMR}$ (75 MHz, DMSO) $\delta 165.7$, 158.0, 157.8, 156.1, 151.9, 151.6, 150.5, 144.8, 143.9, 143.2, 140.7, 135.6, 135.4, 133.4, 132.4, 129.7, $128.9,128.5,128.5,127.8,127.7,127.5,127.4,127.0,126.6,125.8,125.0,120.1,113.1,112.8,86.3$, 85.5, 83.6, 80.3, 69.1, 67.7, 65.2, 63.5, 55.0, 46.8, 37.3, 29.6. $\left(\right.$ ESI $\left.^{+}\right)$: calculated for $\mathrm{C}_{56} \mathrm{H}_{52} \mathrm{~N}_{6} \mathrm{O}_{9}$ $\left(\mathrm{M}+\mathrm{H}^{+}\right): 953.3874$, found 953.3866 .

5'-O-(4,4'-Dimethoxytriphenylmethyl)-2'-O-(9H-fluoren-9-yl-methylcarbonyl)-aminoprop-1-yl-6-Nbenzoyladenosine-3'-O-(2-cyanoethyl N,N-diisopropylphosphoramidite) (13) Compound 12 (120 mg, $0.126 \mathrm{mmol}$ ) dried overnight at high vacuum, was dissolved in $\mathrm{CH}_{2} \mathrm{Cl}_{2}(2 \mathrm{~mL})$ and flushed with $\mathrm{N}_{2}$ for $5 \mathrm{~min}$. DIPEA $(29 \mu \mathrm{L}, 0.166 \mathrm{mmol})$ was added to the reaction mixture followed by $\left(i-\mathrm{Pr}_{2} \mathrm{~N}\right) \mathrm{P}\left(\mathrm{OCH}_{2} \mathrm{CH}_{2} \mathrm{CN}\right) \mathrm{Cl}(37 \mu \mathrm{L}, 0,166 \mathrm{mmol})$. The reaction was stirred for $1 \mathrm{~h}$, at $\mathrm{rt}$, under $\mathrm{N}_{2}$ atmosphere. It was diluted with $\mathrm{CH}_{2} \mathrm{Cl}_{2}(20 \mathrm{~mL})$ and $2.5 \%$ aqueous $\mathrm{NaHCO}_{3}$ solution $(10 \mathrm{~mL})$ was added. Organic layer was separated and aqueous layer was extracted with $\mathrm{CH}_{2} \mathrm{Cl}_{2}(2 \times 10 \mathrm{~mL})$. The combined organic layers were dried over $\mathrm{Na}_{2} \mathrm{SO}_{4}$, filtered and concentrated in vacuo. The residue was 
purified by flash chromatography $\left(\mathrm{CH}_{2} \mathrm{Cl}_{2}\right.$ /acetone, 8:2) to give the desired compound $\mathbf{1 3}$ (850 $\mathrm{mg}$, 90\%) as colorless foam. ${ }^{1} \mathrm{H}-\mathrm{NMR}\left(500 \mathrm{MHz}, \mathrm{CDCl}_{3}\right) \delta 8.91$ (s), 8.72 (d), 8.26 (s), 8.18 (s), 7.93 (d), 7.66 (d), 7.61-7.20 (m), 6.79 (dd), 6.17 (d) 5.22 (br s), 4.74-4.62 (m), 4.44-4.28 (m), 4.20 (t), 3.78 (d), 3.76-3.44 (m), 3.40-3.18 (m), 2.47 (t), 2.30 (t), 1.77 (br s), 1.19-1.05 (m). ${ }^{31} \mathrm{P}$ NMR (500 MHz, $\left.\mathrm{CDCl}_{3}\right) \delta 150.19$, 149.84. HRMS $\left(\mathrm{ESI}^{+}\right)$: calculated for $\mathrm{C}_{65} \mathrm{H}_{69} \mathrm{~N}_{8} \mathrm{O}_{10} \mathrm{P}\left(\mathrm{M}+\mathrm{H}^{+}\right)$: 1153.4918 , found 1153.4952.

Synthesis of dinucleotides 16-21

Dinucleotide-CPG (Fmoc-on) (14). Solutions of 13 (140 mg, $0.12 \mathrm{mmol})$ in MeCN (1 mL) and DCI (450 mg, $3.6 \mathrm{mmol})$ in $\mathrm{MeCN}$ (5.5 mL) were stored separately over $4 \AA \mathrm{MS}$ for $20 \mathrm{~min}$, then mixed together and introduced into the cartridge containing thymidine-CPG (300 mg). The coupling reaction was performed for 25 min with manual mixing. The CPG was washed with $\mathrm{MeCN}(3 \times 5 \mathrm{~mL})$ and dried. To which oxidizing agent $\left(4 \%\right.$ iodine in $\mathrm{THF} /$ pyridine $\left./ \mathrm{H}_{2} \mathrm{O}\right)(2 \mathrm{~mL})$ was added and mixed manually for $30 \mathrm{~min}$. The resulting CPG was washed with DMF $(2 \times 5 \mathrm{~mL}), \operatorname{MeCN}(2 \times 5 \mathrm{~mL})$ and dried to give dinucleotide CPG (325 mg).

Dinucleotide-CPG (Fmoc-off) (15). Dinucleotide-CPG 14 (300 mg) was treated with piperidine $\left(20 \%\right.$ in DMF) $(1 \mathrm{~mL})$ for 20 min at rt. It was washed with DMF $(2 \times 1 \mathrm{~mL}), \mathrm{CH}_{2} \mathrm{Cl}_{2}(2 \times 1 \mathrm{~mL})$ and dried to give Fmoc-off CPG 15 (250 mg).

Dinucleotide (Fmoc-off) (16). Fmoc-off CPG $15(20 \mathrm{mg})$ was treated with aq. $\mathrm{NH}_{4} \mathrm{OH}$ solution $(0.5 \mathrm{~mL})$ for $12 \mathrm{~h}, 55^{\circ} \mathrm{C}$. The solution was filtered-off and dinucleotide 16 was confirmed by HPLC and HR-MS analysis.

General procedure for the synthesis of $\mathbf{1 7 - 2 1}$

A solution of corresponding carboxylic acid (0.019 mmol), HATU (0.019 mmol) and NMM (5 L) in DMF (200 L), was added to the dried Fmoc-off CPG 15. The resulting mixture was stirred for $2 \mathrm{~h}$ at $\mathrm{rt}$ and filtered off. It was further washed with DMF $(2 \times 1 \mathrm{~mL}), \mathrm{MeCN}(2 \times 1 \mathrm{~mL}), \mathrm{CH}_{2} \mathrm{Cl}_{2}(2 \times 1 \mathrm{~mL})$ and dried. The corresponding coupled dinucleotides 17-21 were cleaved from CPG with aq. $\mathrm{NH}_{4} \mathrm{OH}$ solution $(0.5 \mathrm{~mL})$ for $12 \mathrm{~h}, 55^{\circ} \mathrm{C}$ and confirmed by HPLC and HR-MS analysis.

For 21a (DMT off). A solution of azidoacetic acid $(0.019 \mathrm{mmol})$, HATU $(0.019 \mathrm{mmol})$ and NMM (5 L) in DMF (200 L), was added to the dried Fmoc-off CPG 15. The resulting mixture was stirred for $2 \mathrm{~h}$ at $\mathrm{rt}$ and filtered off. It was further washed with DMF $(2 \times 1 \mathrm{~mL}), \mathrm{CH}_{2} \mathrm{Cl}_{2}(2 \times 1 \mathrm{~mL})$ and treated with $1.5 \%$ TFA in $\mathrm{CH}_{2} \mathrm{Cl}_{2}$ for $2 \mathrm{~min}$. Removal of solvent, washing of CPG with $\mathrm{CH}_{2} \mathrm{Cl}_{2}(2 \times 1 \mathrm{~mL})$ and subsequent cleavage with aq. $\mathrm{NH}_{4} \mathrm{OH}$ solution $(0.5 \mathrm{~mL})$ for $12 \mathrm{~h}, 55^{\circ} \mathrm{C}$, afforded the azido dinucleotide (5'-OH) 21a, as confirmed by HPLC and HR-MS analysis.

SPAAC reactions and analysis of $\mathbf{2 0}$ with $\mathbf{2 1}$ and $\mathbf{2 2}$

The solutions of $20(50 \mathrm{~mL})$ and $21(100 \mathrm{~mL})$ or $22(100 \mathrm{~mL}, 1 \mathrm{mg} / 100 \mathrm{~mL})$ in water were mixed for 2 min to afford the $(3+2)$ cycloaddition product, as confirmed by HPLC and HR-MS analysis. 
Synthesis and conjugation of dodecamer ONs 25 and 26

CPG 23 (50 mg) was treated with piperidine (20\% in DMF) (1 mL) for $25 \mathrm{~min}$ at rt. It was washed with DMF $(2 \times 1 \mathrm{~mL}), \mathrm{CH}_{2} \mathrm{Cl}_{2}(2 \times 1 \mathrm{~mL})$ and dried to give Fmoc-off CPG 24 (48 mg). A solution of activated $\mathrm{BCN}$-hydroxysuccinimide carbonate or azidoacid hydroxysuccinimide ester $(0.019 \mathrm{mmol})$ in DMF (100 L) was mixed with CPG $24(20 \mathrm{mg})$, to which DIPEA $(0.029 \mathrm{mmol})$ was added. The resulting mixture was stirred for $12 \mathrm{~h}$ at rt and filtered off. It was further washed with DMF $(2 \times 1 \mathrm{~mL})$, $\mathrm{MeCN}(2 \times 1 \mathrm{~mL}), \mathrm{CH}_{2} \mathrm{Cl}_{2}(2 \times 1 \mathrm{~mL})$ and dried. The corresponding ON-conjugates were cleaved from $\mathrm{CPG}$ with aq. $\mathrm{NH}_{4} \mathrm{OH}$ solution $(0.5 \mathrm{~mL})$ for $12 \mathrm{~h}, 55^{\circ} \mathrm{C}$. Purification on Sep-pak cartridge afforded the ON-conjugates $\mathbf{2 5}$ or 26, respectively, as confirmed by HPLC and MALDI-TOF analysis.

Dimerization of $\mathbf{2 5}$ and $\mathbf{2 6}$ to give $\mathbf{2 7}$

The solutions of $25(50 \mathrm{~L}, 28 \mathrm{nmol})$ and 26 (70 L, $32 \mathrm{nmol})$ in water were mixed for 20 min to afford the $(3+2)$ cycloaddition product 27 , as confirmed by HPLC (Figure S3) and MALDI-TOF analysis.

\section{Preparation of $\mathbf{2 8}$}

Bromoterminated poly(3-hexyl thiophene) $\left(\mathrm{M}_{\mathrm{n}}=3000\right.$, PDI $\left.=1.35\right)$ was reacted with excess amount of sodium azide in $\mathrm{CH}_{2} \mathrm{Cl}_{2}$ overnight. After precipitation in $\mathrm{MeOH}$ and drying, azide-terminated P3HT 28 was obtained as product. FT-IR $\left(\mathrm{cm}^{-1}\right)$ : $3052\left(\gamma_{-\mathrm{C}=\mathrm{CH} \text {, aromatic }}\right), 2952-2854\left(\gamma_{-\mathrm{C}-\mathrm{H} \text { aliphatic }}\right) 2085$ $\left(\gamma_{-\mathrm{N} 3}\right), 1509\left(\gamma_{-\mathrm{C}=\mathrm{C} \text {, asym ring }}\right), 1456\left(\gamma_{-\mathrm{C}=\mathrm{C}, \text { sym ring }}\right), 1376\left(\gamma_{-\mathrm{CH} 3}\right.$, deformation $), 821\left(\gamma_{-\mathrm{C}-\mathrm{H} \text {, aromatic, out-of-plane }}\right)$ and

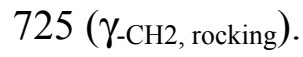

Conjugation of $\mathbf{2 6}$ to polymer $\mathbf{2 8}$

Solution of P3HT-azide $28\left(1 \mathrm{mg} / 10 \mathrm{~mL}\right.$, in $\left.\mathrm{CH}_{2} \mathrm{Cl}_{2}\right)$ was stirred with aqueous slution of BCN conjugated ON 26 for $24 \mathrm{~h}$ at room temperature to get P3HT-ON bioconjugate. Aqueous layer treated several times with DCM to wash out unreacted P3HT.

Preparation of $\mathbf{2 9}$

Solution of P3HT-azide $28\left(1 \mathrm{mg} / 10 \mathrm{~mL}\right.$, in $\left.\mathrm{CH}_{2} \mathrm{Cl}_{2}\right)$ was stirred with aqueous slution of $\mathrm{BCN}$ conjugated ON 26 for $24 \mathrm{~h}$ at room temperature to get $\mathrm{P} 3 \mathrm{HT}-\mathrm{ON}$ bioconjugate. Aqueous layer treated several times with DCM to wash out unreacted P3HT.

\section{Conclusions}

We have successfully demonstrated the suitability of $\mathrm{BCN}$ and derivatives thereof for the preparation of oligonucleotide conjugates by $(3+2)$ cycloaddition with azides. Several BCN-derived phosphoramidites were prepared and incorporated into oligonucleotides with high yield and purity. In addition, an Fmoc-protected 2'-modified adenosine derivative, prepared in only 6 steps from adenosine, served as a versatile building block for both solution and solid phase ON synthesis, thereby allowing the introduction of a functional group at any adenosine during or after oligonucleotide synthesis, and potential extension to other nucleobases (research in progress). The BCN-containing 
oligonucleotides were found to undergo fast SPAAC functionalization or dimerization, and were even suitable for conjugation to lipophilic polymers. The coupling of oligonucleotide to azide-substituted polythiophene opens the possiblity for the construction of a variety of simple field effect transistor biodevices in which sequence specific ON functionalized conjugated polymers are the key component. In a broader context, we have demonstrated the unique combination of reaction efficiency and selectivity of cyclooctyne-based chemistry for the conjugation of sensitive (bio)molecules in aqueous systems, which may be readily extended toward the conjugation of $\mathrm{BCN}$-oligonucleotides to azidecontaining solid surfaces, polymers and large proteins. Finally, we [39] and others [40,41] recently demonstrated that cycloadditions of $\mathrm{BCN}$ is not limited to azides, but $\mathrm{BCN}$ also undergoes extremely fast strain-promoted inverse-electron-demand Diels-Alder cycloaddition (SPIEDAC) with tetrazines. In contrast, benzofused cyclooctynes DBCO and DIBO are inreactive towards tetrazine [42], which further lifts the potential of BCN-modified oligonucleotides for fast and selective bioconjugations, potentially also in vivo [43]. Research along this line, as well as extension of the strategy towards other 2'-O-alkylated nucleobases, is currently ongoing in our laboratory.

\section{Supplementary Materials}

Supplementary materials can be accessed at: http://www.mdpi.com/1420-3049/18/7/7346/s1.

\section{Acknowledgments}

This work was financially supported by the Netherlands Organisation for Scientific Research (NWO, ECHO 700.57.015).

\section{Conflict of Interest}

The authors declare no conflict of interest.

\section{References}

1. Pollack, J.R. DNA microarray technology. Introduction. Methods Mol. Biol. 2009, 556, 1-6.

2. Dagle, J.M.; Weeks, D.L. Oligonucleotide-based strategies to reduce gene expression. Differentiation 2011, 69, 75-82.

3. El-Sagheer, A.H.; Brown, T. Click nucleic acid ligation: Applications in biology and nanotechnology. Acc. Chem. Res. 2012, 45, 1258-1267.

4. Sacca, B.; Niemeyer, C.M. Functionalization of DNA nanostructures with proteins. Chem. Soc. Rev. 2011, 40, 5910-5921.

5. Niemeyer, C.M. Semisynthetic DNA-Protein Conjugates for Biosensing and Nanofabrication. Angew. Chem. Int. Ed. 2010, 49, 1200-1216.

6. Weisbrod, S.H.; Marx, A. Novel strategies for the site-specific covalent labelling of nucleic acids. Chem. Commun. 2001, 5675-5685.

7. Lönnberg, H. Solid-phase synthesis of oligonucleotide conjugates useful for delivery and targeting of potential nucleic acid therapies. Bioconj. Chem. 2009, 20, 1065-1094. 
8. Singh, Y.; Murat, P.; Defrancq, E. Recent developments in oligonucleotide conjugation. Chem. Soc. Rev. 2010, 39, 2054-2070.

9. Lu, K.; Duan, Q.-P.; Ma, L.; Zhao, D.-X. Chemical strategies for the synthesis of peptide-oligonucleotide conjugates. Bioconj. Chem. 2010, 21, 187-202.

10. Singh, Y.; Spinelli, N.; Defrancq, E. Chemical strategies for oligonucleotide-conjugates synthesis. Curr. Org. Chem. 2008, 12, 263-290.

11. Tornøe, C.W.; Christensen, C.; Meldal, H. Peptidotriazoles on solid phase: [1,2,3]-Triazoles by regiospecific copper(I)-catalyzed 1,3-dipolar cycloadditions of terminal alkynes to azides. J. Org. Chem. 2002, 67, 3057-3064.

12. Rostovtsev, V.V.; Green, L.G.; Fokin, V.V.; Sharpless, K.B. A stepwise Huisgen cycloaddition process: Copper(I)-catalyzed regioselective "ligation" of azides and terminal alkynes. Angew. Chem. Int. Ed. 2002, 41, 2596-2599.

13. Kanan, M.W.; Rozenman, M.M.; Sakurai, K.; Snyder, T.M.; Liu, D.R. Reaction discovery enabled by DNA-templated synthesis and in vitro selection. Nature 2004, 431, 545-549.

14. Seela, F.; Pujari, S.S. Azide-Alkyne "Click" Conjugation of 8-Aza-7-deazaadenine-DNA: Synthesis, Duplex Stability and Fluorogenic Dye Labelling. Bioconj. Chem. 2010, 21, 1629-1641.

15. Yamada, T.; Peng, C.G.; Matsuda, S.; Addepalli, H.; Jayaprakash, K.N.; Alam, M.R.; Mills, K.; Maier, M.A.; Charisse, K.; Sekine, M.; et al. Versatile site-specific conjugation of small molecules to siRNA using click chemistry. J. Org. Chem. 2001, 76, 1198-1211.

16. Soriano del Amo, D.; Wang, W.; Jiang, H.; Besanceney, C.; Yan, A.C.; Levy, M.; Liu, Y.; Marlow, F.L.; Wu, P. Biocompatible copper(I) catalysts for in vivo imaging of glycans. J. Am. Chem. Soc. 2010, 132, 16893-16899.

17. Kennedy, D.C.; McKay, C.S.; Legault, M.C.B.; Danielson, D.C.; Blake, J.A.; Pegoraro, A.F.; Stolow, A.; Mester, Z.; Pezacki, J.P. Cellular consequences of copper complexes used to catalyze bioorthogonal click reactions. J. Am. Chem. Soc. 2011, 133, 17993-18001.

18. Eltepu, L.; Jayaraman, M.; Rajeev, K.G.; Manoharan, M. An immobilized and reusable $\mathrm{Cu}(\mathrm{I})$ catalyst for metal ion-free conjugation of ligands to fully deprotected oligonucleotides through click reaction. Chem. Commun. 2013, 49, 184-186.

19. Jayaprakash, K.N.; Geng Peng, C.; Butler, D.; Varghese, J.P.; Maier, M.A.; Rajeev, K.G.; Manoharan, M. Non-nucleoside building blocks for copper-assisted and copper-free click chemistry for the efficient synthesis of RNA conjugates. Org. Lett. 2010, 12, 5410-5413.

20. Van Delft, P.; Meeuwenoord, N.J.; Hoogendoorn, S.; Dinkelaar, J.; Overkleeft, H.S.; van der Marel, G.A.; Filippov, D.V. Synthesis of oligoribonucleic acid conjugates using a cyclooctyne phosphoramidite. Org. Lett. 2010, 12, 5486-5489.

21. Marks, I.S.; Sung Kang, J.; Jones, B.T.; Landmark, K.J.; Cleland, A.J.; Taton, T.A. Strain-promoted "click" chemistry for terminal labeling of DNA. Bioconj. Chem. 2011, 22, 1259-1263.

22. Shelbourne, M.; Chen, X.; Brown, T.; Al-Sagheer, A.H. Fast copper-free click DNA ligation by the ring-strain promoted alkyne-azide cycloaddition reaction. Chem. Commun. 2011, 47, 6257-6259.

23. Santoshkumar, L.K.; Kang, J.S.; Mullen, D.G.; Hast, M.A.; Beese, L.S.; Distefano, M.D.; Taton, T.A. Covalent protein-oligonucleotide conjugates by copper-free click reaction. Bioorg. Med. Chem. 2012, 20, 4532-4539. 
24. Ning, X.; Guo, J.; Wolfert, M.A.; Boons, G.-J. Visualizing metabolically labeled glycoconjugates of living cells by copper-free and fast Huisgen cycloadditions. Angew. Chem. Int. Ed. 2008, 47, 2253-2255.

25. Richardson, J.A.; Gerowska, M.; Shelbourne, M.; French, D.; Brown, T. Six-colour HyBeacon probes for multiplex genetic analysis. ChemBioChem 2010, 11, 2530-2533.

26. Shelbourne, M.; Brown, T. El-Sagheer, A.H.; Brown, T. Fast and efficient DNA crosslinking and multiple orthogonal labelling by copper-free click chemistry. Chem. Commun. 2012, 48, 11184-11186.

27. Lietard, J.; Meyer, A.; Vasseur, J.J.; Morvan, F. An efficient reagent for 5'-azido oligonucleotide synthesis. Tetrahedr. Lett. 2007, 48, 8795-8798.

28. Miller, G.P.; Kool, E.T. Versatile 5'-functionalization of oligonucleotides on solid support: Amines, azides, thiols, and thioethers via phosphorus chemistry. J. Org. Chem. 2004, 69, 2404-2410.

29. Kumar, R.; El-Sagheer, A.H.; Tumpane, J.; Lincoln, P.; Wilhelmsson, L.M.; Brown, T. Template-directed oligonucleotide strand ligation, covalent intramolecular DNA circularization and catenation using click chemistry. J. Am. Chem. Soc. 2007, 129, 6859-6864.

30. Lartia, R.; Murat, P.; Dumy, P.; DeFrancq, E. Versatile introduction of azido moiety into oligonucleotides through diazo transfer reaction. Org. Lett. 2011, 13, 5672-5675.

31. Wada, T.; Mochizuki, A.; Higashiya, S.; Tsuruoka, H.; Kawahara, S.; Ishikawa, M.; Sekine, M. Synthesis and properties of 2-azidodeoxyadenosine and its incorporation into oligodeoxynucleotides. Tetrahedr. Lett. 2001, 42, 9215-9219.

32. Kiviniemi, A.; Virta, R.; Lönnberg, H. Utilization of intrachain 4'-C-azidomethylthymidine for preparation of oligodeoxyribonucleotide conjugates by click chemistry in solution and on a solid support. Bioconj. Chem. 2008, 19, 1726-1734.

33. Aigner, M.; Hartl, M.; Fauster, K.; Steger, J.; Bister, K.; Micura, R. Chemical synthesis of site-specifically 2'-azido-modified RNA and potential applications for bioconjugation and RNA interference. ChemBioChem 2011, 12, 47-51.

34. Fauster, K.; Hartl, M.; Santner, T.; Aigner, M.; Kreutz, C. Bister, K.; Ennifar, E.; Micura, R. 2'-Azido RNA, a versatile tool for chemical biology: Synthesis, X-ray structure, siRNA applications, click labeling. ACS Chem. Biol. 2012, 7, 581-589.

35. Dommerholt, J.; Schmidt, S.; Temming, R.; Hendriks, L.J.A.; Rutjes, F.P.J.T.; van Hest, J.C.M.; Lefeber, D.J.; Friedl, P.; van Delft, F.L. Readily accessible Bicyclononynes for bioorthogonal labeling and three-dimensional imaging of living cells. Angew. Chem. Int. Ed. 2010, 49, 9422-9425.

36. Debets, M.F.; van Berkel, S.S.; Dommerholt, J.; Dirks, A.J.; Rutjes, F.P.J.T.; van Delft, F.L. Bioconjugation with strained alkenes and alkynes. Acc. Chem. Res. 2011, 44, 805-815.

37. Smith, M.B.; March, J. March's Advanced Organic Chemistry, 5th ed.; Wiley: Hoboken, NJ, USA, 2001; pp. 222-225.

38. Jawalekar, A.M.; Meeuwenoord, N.; Cremers, J.G.O.; Overkleeft, H.S.; van der Marel, G.A.; Rutjes, F.P.J.T.; van Delft, F.L. Conjugation of nucleosides and oligonucleotides by [3+2] cycloaddition. J. Org. Chem. 2008, 73, 287-290. 
39. Borrmann, A.; Milles, J.; Plass, T.; Dommerholt, J.; Verkade, J.M.M.; Wießler, M.; Schultz, C.J.; van Hest, C.M.; van Delft, F.L.; Lemke, E.A. Genetic Encoding of a bicyclo[6.1.0]nonynecharged amino acid enables fast cellular protein imaging by metal-free ligation. ChemBioChem 2012, 13, 2094-2099.

40. Chen, W.; Wang, D.; Dai, C.; Hamelberg, D.; Wang, B. Clicking 1,2,4,5-tetrazine and cyclooctynes with tunable reaction rates. Chem. Commun. 2012, 48, 1736-1738.

41. Lang, K.; Davis, L.; Wallace, S.; Mahesh, M.; Cox, D.J.; Blackmann, M.L.; Fox, J.M.; Chin, J.W. Genetic encoding of bicyclononynes and trans-cyclooctenes for site-specific protein labeling in vitro and in live mammalian cells via rapid fluorogenic Diels-Alder reactions. J. Am. Chem. Soc. 2012, 134, 10317-10320.

42. Plass, T.; Milles, S.; Koehler, C.; Schultz, C.; Lemke, E.A. Genetically encoded copper-free click chemistry. Angew. Chem. Int. Ed. 2012, 51, 4166-4170.

43. Rossin, R.; Renart Verkerk, P.; van den Bosch, S.; Vulders, R.; Verel, I.; Lub, J.; Robillard, M. In vivo chemistry for pretargeted tumor imaging in live mice. Angew. Chem. Int. Ed. 2012, 49 , 3375-3378.

Sample Availability: Samples of the compounds 1, 2, 6, 7, 10, 30, 33, 34 are available from the authors.

(C) 2013 by the authors; licensee MDPI, Basel, Switzerland. This article is an open access article distributed under the terms and conditions of the Creative Commons Attribution license (http://creativecommons.org/licenses/by/3.0/). 